\title{
HOW REMOTE/DISTANCE CLASS INSTRUCTION WHEN WORKING WITH INDUSTRY/INSTITUTIONAL PROJECT SPONSORS ON A STUDIO PROJECT CAN BE MANAGED TO PROVIDE A ROBUST EDUCATIONAL EXPERIENCE
}

\author{
Young Mi CHOl and Wendell WILSON \\ Georgia Institute of Technology
}

\begin{abstract}
This paper will examine how remote communication tools such as "BlueJeans" or Microsoft "Teams" can be employed in a studio project to enhance the undergraduate educational experience in the context of remote class instruction.

Junior level students in the School of Industrial Design at the Georgia Institute of Technology take specific themed studio courses, one of which is "Health and Well Being" which is being taught in a "hybrid" delivery mode in response to COVID related concerns. Recognizing that remote instruction could compromise learning opportunities, the course was organized to follow a model used professionally by this author when managing multiple team projects as a design director.

Three projects championed by outside sponsors included (1) the design of paramedic equipment transport solutions; (2) systems to reduce the acuity of Nexxspan medical headwalls in behaviour health or end-of-life scenarios; (3) and development of a system for arterial dialysis. Sponsors included a former fireman/paramedic/alumni, a commercial company that offers a range of hospital equipment management products and a transplant surgeon with the School of Medicine at the University of South Carolina.

Sponsors pitched the projects to the students at the outset of the semester. Students formed teams of 34 students based on their affinity to individual projects; 5 teams being fielded out of a class of 20 students. Teams initially met in person or remotely with their project sponsors to better understand their chosen projects. Users and/or subject matter experts were interviewed remotely during the research process. Remote sessions were held twice weekly with each team to review progress and provide feedback/advice. Each team presented their work to sponsors and the class as a whole at three points during the semester using the BlueJeans application to summarize research, concept development and concept refinement/documentation.

In comparison with comparable projects conducted during previous semesters, it was observed that the option to participate remotely permitted outside sponsors to be MORE available to students with transportation and parking no longer being an impediment. Furthermore, by scheduling focused feedback/input to individual teams via a remote application, the effectiveness and efficiency of the instruction process was optimized for both the students and instructor. The drawbacks of this remote instruction relate more to issues of poor team dynamics or individual students lacking key design skills (which might be better addressed in person). Additionally, it has been observed that students not meeting face-face in studio limits peer-peer competition which decreases individual motivation for improvement in problematic students.
\end{abstract}

Keywords: Industrial design education, studio project, hybrid mode instruction, BlueJeans teleconferencing, health and well being

\section{INTRODUCTION}

Due to the COVID pandemic, the instruction delivery mode for many Industrial Design studio courses within the School of Industrial Design at Georgia Tech were necessarily modified to a remote or hybrid instruction format. In the case of the ID 3031 Health Design Studio offered during the Fall 2020 
semester, instruction was modified to a primarily remote delivery format. (Such studio courses have historically been dependent on "in-person" instruction and "peer-peer" learning to help provide the "studio experience").

This author's approach to studio instruction for upper-level courses has been to coordinate projects with outside sponsors to provide students with the opportunity to work alongside professionals on "real world" projects and give them experience in dealing with marketing and manufacturing concerns. Towards this purpose, several outside entities were contacted to solicit projects for student engagement. 3 projects were identified including (1) the design of systems to reconfigure the acuity level of medical headwalls within "End of Life" (EOL) or "Behavioural Health" $(\mathrm{BH})$ scenarios for a local medical equipment manufacturer; (2) the design of a storage and transport system for assisting EMT/Paramedics with moving lifesaving equipment to a patient's location during medical emergencies; (3) the design of an arterial-based dialysis solution proposed by a transplant surgeon from a regional medical school.

These projects were pitched to the students early in the semester through a series of online sessions. Students formed teams of 3-4 based on project affinity and individual student skills and interests. Virtual meetings were set up with each team during each class period throughout the semester to check on progress and advise. Students were able to set up virtual interviews with project sponsors to address questions/concerns or to get feedback on their ideas. Similar sessions permitted student teams to query subject matter experts. Formal review/presentations were scheduled at three points throughout the semester where students were able to present their research, initial design concepts and final designs to the class and project sponsors via screen sharing.

\section{BACKGROUND}

With the onset of COVID-19, extensive use of remote learning was suddenly required for health and safety. It accelerated the need to implement remote and blended strategies for delivering studio instruction. Design instruction is traditionally studio based where students investigate and solve open ended problems with one-on-one instruction. It is a peer learning environment with immediate feedback. It can be difficult to incorporate new technologies to enable online teaching while replicating this environment. While online instruction provides flexibility, disadvantages include reduced interaction, new obstacles to group work and lack of real time feedback during problem solving [1]. Previous work has shown that effective online/blended studio classes should include opportunities to receive instant peer feedback, ability to track progress, ability for in-context feedback and ability to annotate designs [2].

Effective methods of delivering studio instruction can also be helpful in reducing the gap between learning and practice. The role of a designer is continually updating with remote collaborative tools being increasingly employed [3]. A way to bring this into the classroom is to employ realistic projects with budgets and time constraints to give students a chance to remotely problem solve with peers, instructors, and industry partners [4]. At the same time instructors must re-evaluate how students are assessed. Evidence indicates that some behaviour typically considered as passive, such as viewing other students' work show equal or stronger correlation to student success compared to behaviours traditionally considered as active [5].

This paper presents observations of virtual learning implemented in a design studio class, how it was able to provide more opportunities for project sponsors to interact with students, and how abbreviated team meetings can provide a mechanism for effective and efficient instruction for students.

\section{METHOD}

Three sponsored projects were pitched to the students through a series of online sessions. Students formed teams of 3-4 based on their enthusiasm for a particular project and individual student skills and interests. Each project sponsor provided detail on key project stakeholders, existing competitive and age compensatory solutions, user demographics, key "pinch points" and design opportunities. Email contacts were shared with students. Virtual meetings were set up with each team twice weekly to check on progress and advise them on where further effort might be needed. Students were able to set up virtual interviews with project sponsors to address questions/concerns or to get feedback on their ideas. Students were also able to set up interviews with subject matter experts using remote conferencing applications such as BlueJeans or Microsoft Teams. Formal review/presentations were scheduled at three points throughout the semester where students were able to present their research, design concepts and final designs to the class and project sponsors via screen sharing. 
Several teams made use of idea sharing applications such as Figma (www.figma.com) which permitted them to share information and ideas in real-time, as well as facilitating reporting of team progress. This proved to be more effective than more traditional virtual file sharing tools such as Google Drive.

Teams initially presented background research in order to get buy in from project sponsors, ensuring that they adequately understood the problem, user needs and state of the art of available solutions. These presentations included infographics relating stakeholders, user personas representing significant portions of the user population, journey maps detailing how users currently address the chosen problems, matrices outlining current available solutions and how they compare against various determining parameters. Of particular interest was information regarding compensatory solutions that are currently used by users to address the problem. Similarly, students explored information regarding related technologies that might be employed in proposed solutions.

Once the problem scope had been adequately understood, using a visual ideation technique, each team produced a range of ideas in a thumbnail sketch format. Concept proposals were mapped using morphological matrices. Each team developed 3-4 concepts using a combination of analogue and digital tools. Each concept was represented in a series of images showing appearance, organizational detail, assembly detail, general scale and dimensional information and proposed use methodologies.

Consensus was solicited from fellow classmates, project sponsors and the course instructor regarding the relative merit of these initial concepts. In most instances, teams were able to proceed with refining a final direction based on feedback received in the concept review. The teams addressing the paramedic/EMT storage/transport solution required additional time to work more closely with the project sponsor to develop solutions that were deemed to be both realistic and creative. The ability to conference directly with the sponsor facilitated additional brainstorming and concept review.

Each team refined their chosen design concepts using CAD - specifically SolidWorks or Fusion360. Final concepts were represented by detailed CAD models presented in a series of static images and/or animations that detailed how the solution could be assembled, used, and operated. The industry partners were pleased with the final team results, particularly the sponsors of the Dialysis and Headwall related projects.

Table 1. Comparison and Explanation of Team Output

\begin{tabular}{|c|c|c|}
\hline Team Makeup: & General Quality of Output: & Possible Explanation: \\
\hline $\begin{array}{l}\text { Team \# } 1 \\
\text { (Headwall Project) } \\
3 \text { Students }\end{array}$ & $\begin{array}{l}\text { High quality output well received } \\
\text { by Sponsor }\end{array}$ & $\begin{array}{l}+ \text { Good team makeup } \\
+ \text { Effective team communications }\end{array}$ \\
\hline $\begin{array}{l}\text { Team \# } 2 \\
\text { (EMT/Paramedic } \\
\text { Transport Project) } \\
4 \text { Students }\end{array}$ & $\begin{array}{l}\text { Mixed level output needing further } \\
\text { development } \\
\text { Not well received by Sponsor }\end{array}$ & $\begin{array}{l}\text { - Persistent team dynamic issues } \\
\text { - Skill weaknesses } \\
\text { - Team stopped communicating } \\
\text { with Sponsor, Instructor } \\
\text { or one another } \\
\text { - Sponsor was GT ID alumni who } \\
\text { may have had higher-than-usual } \\
\text { expectations }\end{array}$ \\
\hline
\end{tabular}




\begin{tabular}{|c|c|c|}
\hline $\begin{array}{l}\text { Team \# } 3 \\
\text { (EMT/Paramedic } \\
\text { Transport Project) } \\
4 \text { Students }\end{array}$ & $\begin{array}{l}\text { Good quality output needing } \\
\text { further development } \\
\text { Well received by Sponsor }\end{array}$ & $\begin{array}{l}\text { + Team made extensive use of } \\
\text { Figma to manage group effort } \\
\text { - Sponsor was GT ID alumni who } \\
\text { may have had higher-than-usual } \\
\text { expectations } \\
\text { + Effective team communications }\end{array}$ \\
\hline $\begin{array}{l}\text { Team \# } 4 \\
\text { (Headwall Project) } \\
3 \text { Students }\end{array}$ & $\begin{array}{l}\text { High quality output well received } \\
\text { by Sponsor }\end{array}$ & $\begin{array}{l}+ \text { Good team makeup } \\
+ \text { Effective team communications }\end{array}$ \\
\hline $\begin{array}{l}\text { Team \# } 5 \\
\text { (Arterial Dialysis } \\
\text { Project) } \\
4 \text { Students }\end{array}$ & $\begin{array}{l}\text { Exceptionally high-quality output } \\
\text { well received by Sponsor }\end{array}$ & $\begin{array}{l}+ \text { Effective team networking with } \\
\text { Subject Matter experts } \\
+ \text { Effective team communications } \\
+ \text { Highly skilled and motivated team } \\
\quad \text { leader }\end{array}$ \\
\hline
\end{tabular}

\section{RESULTS AND DISCUSSION}

It was observed that scheduled online review/coaching sessions with each team permitted pertinent details to be shared without wasting the time of other students. Although each team was comprised of 3-4 students, the ability to interact with them individually as well as collectively to provide regular feedback and input without requiring everyone involved to be located in one place made the process less cumbersome and more efficient.

This virtual approach permitted sponsors and subject matter experts to interact with teams on a more regular basis as it did not involve the time, transportation or parking logistics normally associated with typical in-person campus collaboration. As such, outside sponsors were MORE available to the student teams than they would typically have been under normal circumstances.

Table 2. Advantages and Disadvantages associated with Virtual Interaction in Comparison with Traditional Face to Face Classroom Interaction

\begin{tabular}{|l|l|l|}
\hline $\begin{array}{l}\text { Comparison } \\
\text { Criteria: }\end{array}$ & $\begin{array}{l}\text { Traditional Face to Face } \\
\text { Interaction: }\end{array}$ & Virtual Sponsor Participation: \\
\hline $\begin{array}{l}\text { Willingness of } \\
\text { Sponsor or } \\
\text { "Project } \\
\begin{array}{l}\text { Champion" to } \\
\text { field project: }\end{array}\end{array}$ & $\begin{array}{l}\text { Varies depending on sponsor } \\
\text { and project }\end{array}$ & $\begin{array}{l}\text { + More likely due to reduced logistical } \\
\text { hurdles (time/transportation/parking) } \\
\text { + Sponsors can participate from anywhere } \\
\end{array}$ \\
& $\begin{array}{l}\text { + Reduced Time/Cost of participation } \\
+ \text { Involvement can be more "casual" } \\
\text { - Potential for reduced sponsor } \\
\text { "commitment" due to inherent "distance" } \\
\text { of interaction }\end{array}$ \\
\hline
\end{tabular}




\begin{tabular}{|c|c|c|}
\hline $\begin{array}{l}\text { Initial Project } \\
\text { Introduction by } \\
\text { Sponsors: }\end{array}$ & $\begin{array}{l}\text { Typically done In-Person } \\
\text { + Increased respect for sponsors } \\
\text { by students when meeting } \\
\text { sponsors face to face } \\
\text { + Increased respect for sponsors } \\
\text { that may result from actual site } \\
\text { visit to sponsoring entity }\end{array}$ & $\begin{array}{l}\text { + Easier due to reduced logistical Hurdles } \\
\text { (time/transportation/parking) } \\
\text { - Lack of face to face meeting may lead } \\
\text { to less respect for sponsors by students } \\
\text { and vice versa } \\
\text { + Students, instructors, and sponsors can } \\
\text { participate from anywhere }\end{array}$ \\
\hline $\begin{array}{l}\text { Student Project } \\
\text { Management: }\end{array}$ & $\begin{array}{l}\text { Typically done in studio or via } \\
\text { email or text }\end{array}$ & $\begin{array}{l}\text { + Use of virtual conferencing provides } \\
\text { ability to share } 2 D / 3 D \text { work in real-time } \\
\\
+ \text { Use of file sharing technologies helps } \\
\text { coordinate efforts of group and } \\
\text { provides more peer-peer synergy }\end{array}$ \\
\hline $\begin{array}{l}\text { Ongoing } \\
\text { Project Input } \\
\text { and Feedback } \\
\text { from Instructor } \\
\text { and Sponsors: }\end{array}$ & $\begin{array}{l}\text { Typically sponsor input and } \\
\text { feedback is done via email } \\
\text { - Often sponsor responses are } \\
\text { not responsive or timely } \\
\text { - Inability for sponsors to } \\
\text { review } 2 D \text { or } 3 D \text { student work } \\
\text { (aside from email attachments) }\end{array}$ & $\begin{array}{l}+ \text { Increased frequency due to reduced } \\
\text { logistical hurdles } \\
\text { (time/transportation/parking) } \\
+ \text { Ability to share } 2 D \text { and } 3 D \text { work in real } \\
\text { time with sponsors via screen sharing } \\
+ \text { Nature of virtual sessions makes } \\
\text { Q and A more responsive and timely in } \\
\text { comparison with email } \\
+ \text { Sponsors are potentially more } \\
\text { responsive and flexible due to reduced } \\
\text { logistical hurdles } \\
\text { (time/transportation/parking) } \\
+ \text { Students, instructors, and sponsors can } \\
\text { participate from anywhere } \\
\text { - Possibly reduced perceived } \\
\text { importance of virtual meetings due to } \\
\text { lack of direct personal contact } \\
\text { - Potential opportunity for reduced } \\
\text { attention due to virtual format on part } \\
\text { of both students and sponsors } \\
+ \text { Ability to easily meet with individual } \\
\text { students/ teams increases overall } \\
\text { efficiency of class since “waiting for } \\
\text { your turn" is eliminated. }\end{array}$ \\
\hline $\begin{array}{l}\text { Sponsor } \\
\text { Participation in } \\
\text { Project } \\
\text { Reviews and } \\
\text { Presentations: }\end{array}$ & $\begin{array}{l}\text { Typically done In-Person } \\
\text { - Availability of sponsors } \\
\text { can vary widely depending on } \\
\text { company/institution scheduling }\end{array}$ & $\begin{array}{l}\text { + Increased potential for participation } \\
\text { of additional sponsor representatives } \\
\text { due to reduced logistical hurdles. } \\
\text { (time/transportation/parking) }\end{array}$ \\
\hline
\end{tabular}


Use of idea sharing applications such as Figma allowed students to better coordinate their efforts as it was possible for all involved to review the work of classmates on a continuing basis, as opposed to seeing the work of fellow students only periodically. Certainly, it permitted more synergy to take place where the work of one student could more readily be leveraged and developed further by another.

\section{CONCLUSIONS AND RECOMMENDATIONS}

Although the observations made in this paper are anecdotal, based upon a single semester's work and all assessment of the results is admittedly qualitative (as opposed to quantitative), it appears that virtual conferencing with students/project sponsors can offer substantial advantages over traditional face-face interactions when implemented effectively. There seems to be a great opportunity for layering this virtual instruction onto traditional face-to-face techniques to achieve a robust studio experience.

Whether or not pandemic circumstances dictate that social distancing and virtual learning continue to be the rule, online conferencing should continue to be used to achieve more effective and efficient communication with students and project sponsors. Leveraging this technique with face-face instruction should provide the best of both worlds in terms of instructor input/feedback while still permitting regular and efficient review of individual and/or teamwork. It also provides a relatively pain-free way for outside sponsors and subject matter experts to interact with students. As such, it should expand opportunities for the participation of these individuals to provide input and feedback on a much more regular basis as well as the sponsorship of such real-world projects in the first place.

Specifically, it is recommended that future studio courses featuring design projects conducted with outside sponsors be organized so as to leverage virtual communications (1) in place of or (2) in addition to traditional face-face interaction to maximize the value of such relationships. It is also recommended that course instruction be structured to include both (1) traditional classroom instruction (large group basis); (2) and more focused support of individual students or project teams (small group basis) using virtual communications in order to maximize input/feedback \& overall class efficiency.

\section{REFERENCES}

[1] Fleischmann K. (2020). Online design education: Searching for a middle ground. Arts and Humanities in Higher Education, 19(1), 36-57.

[2] Fleischmann K. (2018). Hype or help? Technology-enhanced learning in the design classroom: an experiment in online design collaboration. International Journal of Arts and Sciences, 11(1), 331-341.

[3] Masdéu M. and Fuses J. (2017). Reconceptualizing the design studio in architectural education: Distance learning and blended learning as transformation factors. ArchNet-IJAR: International Journal of Architectural Research, 11(2), 6.

[4] Rodriguez C., Hudson R., and Niblock C. (2018). Collaborative learning in architectural education: Benefits of combining conventional studio, virtual design studio and live projects. British Journal of Educational Technology, 49(3), 337-353.

[5] Jones D., Lotz N., and Holden G. (2017). Lurking and learning: Making learning visible in a Virtual Design Studio. 